\title{
Kualitas Tidur dan Tingkat Stress berhubungan dengan Status Gizi Orang Dewasa pada Masa Pandemi Covid 19
}

\author{
Avifah Normalia Isti ${ }^{1}$, Debby Endayani Safitri ${ }^{1}$, Endayani Safitri $^{2}$, Imas Arumsari \\ ${ }^{1}$ Universitas Muhammadiyah Prof. Dr. Hamka, Jakarta \\ Korespondensi E-mail: avifahnormalia98@gmail.com
}

Submitted: 16 Maret 2021, Revised: 29 Oktober 2021, Accepted: 25 November 2021

\begin{abstract}
Nutritional status is one of the factors that influence the quality of human resource. Nutritional status in early adultbood is influenced by energy intake and macro nutrients, physical activity, sleep quality, stress level and screen time. The purpose of this study was to identify the relationship between energy intake, macro nutrients, physical activity, sleep quality, stress levels and screen time with nutritional status in early adulthood in Kota Bambu Utara Village. This study used cross sectional study design and the total sample was 80 people. Primary data collected were body weight and height, energy intake and macro nutrient intake data was assessed by $2 \times 24$ bour food recall questionnaire, physical activity data using the Physical Activity Level (PAL), sleep quality data using the Pitsburg sleep quality index (PSQI), stress level data using the Depression, Anxiety, Stress Scale (DASS14) and screen time data using a screen time questionnaire. Statistical analysis showed that sleep quality is associated with nutrition status (p-value $<0.05)$. Stress level is associated with nutrition status (p-value $<0.05$ ). Meanwbile, nutrition status is not associated with macronutrient, protein, and carbobydrate intake including screen time. The conclusion from this research show that sleep quality and stress level were associated with nutrition status.
\end{abstract}

Keyword: sleep, stress level, nutrional status, intake

\begin{abstract}
Abstrak
Status gizi merupakan salah satu faktor yang mempengaruhi kualitas sumber daya manusia. Status gizi pada dewasa awal dipengaruhi oleh asupan energi, zat gizi makro, aktivitas fisik, tingkat stress dan screen time. Tujuan dari penelitian ini adalah untuk melihat hubungan antara asupan energi dan zat gizi makro, aktivitas fisik, kualitas tidur, tingkat stres, dan screen time dengan status gizi pada dewasa awal di Kelurahan Kota Bambu Utara. Penelitian ini menggunakan desain studi cross sectional. Data primer yang dikumpulkan yaitu berat badan dan tinggi badan, data asupan energi dan zat gizi makro menggunakan kuesioner food recall 2 × 24 jam, data aktivitas fisik menggunakan kuesioner Physical Activity Level (PAL), data kualitas tidur menggunakan kuesioner Pitsburg Sleep Quality Index (PSQI), data tingkat stress menggunakan Depression, Anxiety, Stress Scale (DASS14), serta data screen time menggunakan kuesioner screen time. Hasil uji statistik menunjukkan bahwa kualitas tidur berhubungan dengan status gizi $(p$-value $<0.05)$. Tingkat stress secara signifikan juga berhubungan dengan status gizi ( $p$-value $<0.05)$. Sementara itu, status gizi tidak berhubungan dengan asupan energi, protein, karbohidrat dan screen time. Kesimpulan dari penelitian ini adalah kualitas tidur dan tingkat stress perlu diperbaiki untuk mempertahankan status gizi yang optimal.
\end{abstract}

Kata Kunci: tidur, level stress, status gizi, asupan

\section{Pendahuluan}

Fase dewasa awal atau dewasa muda merupakan peralihan seseorang dari masa remaja menjadi masa tua (1). Pada masa tersebut dikenal dengan masa produktif, ditandai dengan pencapaian tingkatan pendidikan, kemapanan hidup, dan kesuksesan karier (2). Peningkatan sumber daya manusia (SDM) di masa dewasa tersebut dapat diwujudkan melalui pembangunan dalam sektor kesehatan. Status gizi yang baik merupakan salah satu faktor meningkatnya kualitas sumber daya manusia (3). Status gizi dewasa awal disebabkan oleh banyak faktor diantaranya yaitu, faktor keturunan, gaya hidup dan faktor lingkungan (4). Overweight dan obesitas merupakan masalah gizi yang saat ini mendominasi pada kelompok dewasa awal di Indonesia (5). Konsekuensi yang ditimbulkan dari overveight dan obesitas di masa tersebut adalah penyakit diabetes militus tipe II, jantung koroner, dyslipidemia, ostheoarthiritis dan penyakit degeneratif lainnya (2).

Beberapa faktor gaya hidup yang diketahui mampu mempengaruhi status gizi adalah aktivitas fisik. Aktivitas fisik dibutuhkan untuk salah satu upaya menyeimbangkan antara pengeluaran dan pemasukan zat gizi sehingga diharapkan dapat membuat berat badan menjadi ideal. Aktivitas fisik pada dewasa cenderung 
rendah yang disebabkan oleh beberapa faktor seperti kesibukan dan gaya hidup yang kurang baik (6). Selain aktivitas fisik, faktor gaya hidup lainnya yang dapat memengaruhi status gizi adalah kualitas tidur. Kualitas tidur ini mengandung beberapa komponen yang meliputi waktu yang diperlukan untuk memulai tidur (sleep latency), durasi tidur (sleep duration), presentase antara banyaknya waktu tidur dengan waktu yang dihabiskan di tempat tidur (sleep efficiency), gangguan tidur yang sering dialami pada malam hari (sleep disturbance), penggunaan obat tidur, gangguan yang biasa dialami saat siang hari dan kualitas tidur secara subjektif (subjective sleep quality) (7).

Faktor lainnya yang juga penting diperhatikan adalah tingkat stres. Tidak dapat dihindari masa dewasa awal cukup rentan terhadap permasalahan. Permasalahan ini bisa didapatkan dari faktor internal maupun eksternal. Stress internal dalam tubuh mampu mempengaruhi respon tubuh seseorang terhadap stress. Sementara itu, kondisi tubuh yang stres akan memengaruhi perilaku makan. Apalagi saat ini pandemi Covid19 masih melanda seluruh dunia. Prevalensi gangguan mental meningkat tajam saat pandemi Covid-19 (8). Fase dewasa yang didominasi fase produktif mengalami perubahan gaya hidup. Kondisi ini, tentu memberikan tantangan sendiri dalam menjalani gaya hidup. Gaya hidup menjadi lebih sedentary sejak pandemic dimulai. Penelitian menunjukkan bahwa jumlah langkah menurun, waktu tidur meningkat, waktu untuk bersosialisasi berkurang dan waktu untuk melihat layar menjadi bertambah (9). Semenjak pandemi, hampir semua sendi kehidupan memerlukan bantuan teknologi, sehingga screen time menjadi bertambah konsumsinya. Screen time adalah waktu yang dipakai dalam penggunaan alat elektronik seperti komputer, laptop, pemakaian gadget, bermain game online, dan menonton video (10). Meningkatnya durasi screen time akan mengurangi waktu untuk melakukan aktivitas fisik dan juga dapat memengaruhi pola konsumsi makanan karena pengaruhiklan di berbagai media (11). Sejauh ini, masih terbatas penelitian yang mengamati hubungan antara asupan energi dan zat gizi makro, aktivitas fisik, kualitas tidur, tingkat stres dan screen time dengan status gizi pada orang dewasa di Kelurahan Kota Bambu Utara, Kecamatan Palmerah, Jakarta Barat selama pandemi Covid 19. Jakarta adalah Ibu kota Indonesia yang merupakan pusat industri dan pemerintahan. Sangat penting memahami faktor-faktor yang mempengaruhi gaya hidup penduduk yang bekerja di Jakarta, untuk memudahkan memahami beban dan tantangan dalam pencapaian pekerjaan yang sangat dipengaruhi oleh faktor fisik dari pekerja itu sendiri.

\section{Metode Penelitian}

Penelitian ini dilakukan dengan menggunakan metode studi kuantitatif dengan desain studi cross sectional yang dilakukan pada bulan September 2020 di Kelurahan Kota Bambu Utara, Kecamatan Palmerah, Jakarta Barat. Populasi dalam penelitian ini adalah seluruh dewasa awal dengan usia 19 - 25 tahun di RW 01, Kelurahan Kota Bambu Utara. Sampel pada penelitian ini yaitu 80 orang dewasa awal yang memenuhi kriteria inklusi. Teknik sampel yang dilakukan dengan menggunakan teknik simple random sampling. Data yang dikumpulkan yaitu karakteristik responden meliputi jenis kelamin dan usia, data antropometri meliputi berat badan dan tinggi badan lalu dikonversikan dalam bentuk IMT, data asupan energi dan zat gizi makro menggunakan form food recall 2x24 jam (12), data aktivitas fisik menggunakan kuesioner Physical Activity Level (PAL) (13), data kualitas tidur menggunakan kuesioner Pitssburgh Slepp Quality Index (PSQI) (14), data tingkat stres menggunakan kuesioner Depression Axiety Stres Scale (DASS) (15), dan data screen time menggunakan kuesioner screen time $2 \times 24$ jam. Analisis data pada penelitian ini terdiri dari dua yaitu analisis univariat untuk melihat gambaran dan analisis bivariat untuk melihat hubungan antara variabel independen dengan variabel dependen dengan menggunakan perangkat lunak statistik.

\section{Hasil dan Pembahasan \\ Karakteristik Umum Responden}

Data karakteristik responden seperti terlihat pada tabel 1, dimana responden laki-laki sebanyak 33,8\% dan responden perempuan sebanyak 66,3\%. Dari distribusi usia menunjukkan bahwa responden paling banyak berada pada usia 19 dan 22 tahun yaitu masing-masing sebanyak 20 orang (25\%) dan 19 orang (23,8\%), sedangkan untuk usia 20,21,23, 24 dan 25 tahun masing-masing sebanyak 12 orang (15\%), 7 orang $(8,8 \%), 6$ orang $(7,5 \%), 6$ orang $(7,5 \%)$ dan 10 orang $(12,5 \%)$. Untuk data status gizi, Sebagian besar reponden memiliki status gizi normal yaitu sebanyak $60 \%$. Sedangkan responden yang memiliki status gizi lebih sebanyak $28,8 \%$ dan responden yang memiliki status gizi kurang sebanyak $11,2 \%$. Sementara itu, data asupan energi dan zat gizi makro menunjukkan sebagian besar responden memiliki asupan energi, protein, lemak dan karbohidrat 
yang cukup. Proporsi asupan energi responden pada kategori asupan lebih sebanyak 3,8\%. Asupan protein, lemak dan karbohidrat pada responden dengan kategori asupan lebih secara berurutan sebanyak 30\%, 15\% dan 1,3\%. Secara lebih lengkapnya dapat dilihat pada Tabel 1.

Untuk variable aktivitas fisik, semua responden memiliki aktivitas fisik ringan yaitu 80 orang $(100 \%)$. Distribusi responden berdasarkan kualitas tidur menunjukkan bahwa responden yang memiliki kualitas tidur baik lebih banyak yaitu sebesar 68,8\% dibandingkan dengan responden dengan kualitas tidur buruk yaitu sebesar 31,3\%. Distribusi responden berdasarkan tingkat stres menunjukkan bahwa responden yang stres lebih banyak yaitu 58,8\% dibandingkan dengan responden yang tidak stress yaitu 41,3\%. Distribusi responden berdasarkan screen time menunjukkan bahwa responden yang memiliki screen time tinggi sebesar 55\%, dimana lebih banyak bila dibandingkan dengan responden yang memiliki screen time rendah yaitu $45 \%$. Secara lebih lengkap, hal tersebut dapat dilihat pada Tabel 1 dibawah.

\section{Hubungan Asupan dengan Status Gizi}

Responden dengan asupan energi yang kurang dan cukup, lebih banyak memiliki status gizi lebih yaitu 21 orang $(27,3 \%)$ daripada responden dengan asupan energi lebih yaitu 2 orang (66.7\%). Hasil uji statistik menunjukkan tidak ada hubungan yang signifikan antara asupan energi dengan status gizi $(p>0,05)$. Penelitian ini sejalan dengan penelitian Rahmawati (2017) mengenai asupan energi dan zat gizi terhadap status gizi mahasiswa STIKES PKU Muhammadiyah Surakarta yang menunjukkan tidak ada hubungan antara asupan energi dengan status gizi dengan $p$-value $=0,227$. Responden dengan asupan protein kurang-cukup, lebih banyak memiliki status gizi lebih yaitu 12 orang $(21,4 \%)$ daripada responden dengan asupan protein yang lebih yaitu 11 orang $(45,8 \%)$. Hasil uji statistik menunjukkan tidak ada hubungan yang signifikan antara asupan protein dengan status gizi $(\mathrm{p}>0,05)(16)$. Hal ini sejalan dengan penelitian Poetry, dkk (2020) yang menunjukkan tidak terdapat hubungan antara asupan protein dengan status gizi pada mahasiswa Fakultas Kesehatan Masyarakat Universitas Airlangga dengan $p$-value $=0,166$. Responden dengan asupan lemak kurang-cukup, lebih banyak memiliki status gizi lebih yaitu 18 orang $(26,5 \%)$ daripada responden dengan asupan lemak yang lebih yaitu 5 orang $(41,7 \%)$. Hasil uji statistik menunjukkan tidak ada hubungan yang signifikan antara asupan lemak dengan status gizi $(\mathrm{p}>0,05)(17)$. Hasil dari penelitian Rahmawati (2017) juga menunjukkan tidak adanya hubungan antara asupan lemak dengan status gizi dengan p-value $=0,218$. Responden dengan asupan karbohidrat kurang-cukup memiliki status gizi lebih sebanyak 23 orang (29,1\%), sedangkan tidak ada responden dengan asupan karbohidrat yang lebih dengan status gizi lebih. Hasil uji statistik menunjukkan tidak ada hubungan yang signifikan antara asupan karbohidrat dengan status gizi ( $>00,05)$ (16). Hal ini sejalan dengan penelitian Poetry, dkk (2020) mengenai hubungan asupan energi dan zat gizi makro dengan status gizi mahasiswa Fakultas Kesehatan Masyarakat Universitas Airlangga yang menyatakan tidak ada hubungan antara asupan karbohidrat terhadap status gizi dengan $p$-value $=0,920$ (17). Hasil penelitian menunjukkan responden yang gizi lebih memiliki asupan zat gizi makro yang rendah. Hal ini sejalan dengan review systematis yang menyebutkan bahwa orang dengan gizi lebih cenderung melaporkan konsumsi makanan yang lebih rendah (18). Penggunaan metode recall memang tidak bisa mengambarkan konsumsi makanan biasanya. Metode recall, sangat mengandalkan memori, kerjasama dan kemampuan komunikasi.

\section{Hubungan Kualitas Tidur Dan Status Gizi}

Responden dengan kualitas tidur yang buruk lebih banyak memiliki status gizi lebih yaitu sebesar 15 orang $(60 \%)$ dibandingkan dengan responden yang memiliki kualitas tidur baik yaitu sebanyak 8 orang $(14,5 \%)$. Hasil Uji Chi Square menunjukkan adanya hubungan yang signifikan antara kualitas tidur dengan status gizi ( $p$ value $=0,00)$. Prevalence Ratio (PR) menunjukkan nilai 4,12 (95\% CI 2,01 - 8,44). Hal ini mengindikasikan bahwa orang dewasa yang memiliki kualitas tidur yang buruk beresiko 4,12 kali mengalami status gizi lebih. Hal ini sejalan dengan penelitian Sumarna, dkk (2020) mengenai hubungan antara obesitas dengan kualitas tidur pada mahasiswa fakultas keperawatan universitas padjajaran, yang mana hasil menunjukkan terdapat hubungan yang signifikan antarakualitas tidur dengan obesitas dengan $p$-value $=0,003$. Responden dengan tingkat stres

Nutrire Diaita Vol.13, No.02, Oktober 2021 ,p.48-55 
Tabel 1. Distribusi karakteristik responden, status gizi, asupan energi dan zat gizimakro, aktivitas fisik, kualitas tidur, tingktak stress dan screen time

\begin{tabular}{|c|c|c|}
\hline Variabel & $\mathbf{N}$ & $\%$ \\
\hline \multicolumn{3}{|l|}{ Jenis Kelamin } \\
\hline Laki-laki & 27 & 33,8 \\
\hline Perempuan & 53 & 66,3 \\
\hline \multicolumn{3}{|l|}{ Usia } \\
\hline 19 & 20 & 25 \\
\hline 20 & 12 & 15 \\
\hline 21 & 7 & 8,8 \\
\hline 22 & 19 & 23,8 \\
\hline 23 & 6 & 7,5 \\
\hline 24 & 6 & 7,5 \\
\hline 25 & 10 & 12,5 \\
\hline \multicolumn{3}{|l|}{ Status Gizi } \\
\hline Kurang & 9 & 11,2 \\
\hline Normal & 48 & 60 \\
\hline Lebih & 23 & 28,8 \\
\hline \multicolumn{3}{|l|}{ Asupan Energi } \\
\hline Kurang & 19 & 23,8 \\
\hline Cukup & 58 & 72,5 \\
\hline Lebih & 3 & 3,8 \\
\hline \multicolumn{3}{|l|}{ Asupan Protein } \\
\hline Kurang & 7 & 8,8 \\
\hline Cukup & 49 & 61,3 \\
\hline Lebih & 24 & 30 \\
\hline \multicolumn{3}{|l|}{ Asupan Lemak } \\
\hline Kurang & 17 & 21,3 \\
\hline Cukup & 51 & 63,8 \\
\hline Lebih & 12 & 15,0 \\
\hline \multicolumn{3}{|c|}{ Asupan Karbohidrat } \\
\hline Kurang & 24 & 30 \\
\hline Cukup & 55 & 68,8 \\
\hline Lebih & 1 & 1,3 \\
\hline \multicolumn{3}{|l|}{ Aktivitas Fisik } \\
\hline Ringan & 80 & 100 \\
\hline \multicolumn{3}{|l|}{ Kualitas Tidur } \\
\hline Baik & 25 & 31,3 \\
\hline Buruk & 55 & 68,8 \\
\hline \multicolumn{3}{|l|}{ Tingkat Stress } \\
\hline Tidak Stres & 47 & 58,8 \\
\hline Stres & 33 & 41,3 \\
\hline \multicolumn{3}{|l|}{ Screen Time } \\
\hline Rendah & 44 & 55 \\
\hline Tinggi & 36 & 45 \\
\hline
\end{tabular}

yang berada pada kategori stres, lebih banyak memiliki status gizi lebih yaitu 22 orang (71\%) dibandingkan dengan responden yang tingkat stres nya berada pada kategori tidak stres yaitu sebanyak 1 orang $(2 \%)$. Hasil Uji Chi Square menunjukkan adanya hubungan signifikan antara tingkat stres dengan status gizi $(p$-value $=0,00)$. Prevalence Ratio (PR) menunjukkan nilai 7,37 (95\% CI 1,85 - 29,31). Artinya orang dewasa yang memiliki tingkat stres pada kategori stres beresiko 7,37 kali mengalami status gizi lebih (19).

\section{Hubungan Screen Time dengan Status Gizi}

Responden dengan screen time yang tinggi lebih banyak memiliki status gizi lebih yaitu 13 orang (36,1\%) daripada responden dengan screen time yang rendah yaitu 10 orang (22,7\%). Hasil Uji Chi Square menunjukkan 
tidak ada hubungan antara screen time dengan status gizi ( $p$-value $=0,28)$. Hasil penelitian sejalan dengan penelitian yang dilakukan oleh Pratiwi \& Mardiyati (2018) yang menunjukkan bahwa tidak terdapat hubungan antara screen time dengan kenaikan berat badan (20).

Status gizi adalah kondisi reaksi antara asupan zat gizi yang berasal dari makanan terhadap kebutuhan gizi yang dibutuhkan untuk proses metabolisme tubuh. Setiap orang memiliki asupan zat gizi yang berbeda, hal tersebut berdasarkan pada jenis kelamin, usia, aktivitas fisik, berat badan dan lainnya (2). Asupan energi diperlukan untuk aktivitas otot, memelihara suhu tubuh, dan memperbaiki jaringan. Sumber energi dapat berasal dari karbohidrat, protein, dan lemak (21). Pada penelitian ini sebagian besar responden yang status gizi nya lebih mempunyai asupan energi dan zat gizi makro yang kurang dan cukup. Hal tersebut menunjukkan gizi lebih pada responden tidak disebabkan oleh asupannya. Penyebab gizi lebih pada seseorang dapat dipengaruhi oleh beberapa faktor diantaranya yaitu faktor keturunan, hormon, sosial serta lingkungan seperti life style dan kebiasaan makan dan aktivitas fisik yang kurang baik (22). Tubuh orang yang obesitas atau gizi lebih mempunyai kecenderungan menyimpan makanan lebih banyak daripada yang dikonsumsi sehingga dapat dikatakan proses metabolisme tubuhnya lambat. Setiap orang memiliki daya serap makanan dalam tubuh yang berbeda-beda. Ada orang yang memiliki daya serap terhadap makanan yang tinggi sehingga orang tersebut akan tetap mengalami kegemukan walaupun porsi makannya cukup atau sedikit, hal ini dikarenakan semua kalori dari makanan yang dikonsumsi terserap dengan maksimal (23). Pada penelitian ini terdapat kekurangan dimana proses pengambilan data asupan menggunakan metode food recall 2 x 24 jam dengan bantuan buku foto makanan yang mengandalkan ingatan responden sehingga dapat bersifat subjektif. Akan lebih baik jika menggunakan metode penimbangan makanan sehingga dapat menggambarkan asupan energi responden secara lebih akurat. Meskipun pada penelitian ini menunjukkan tidak ada hubungan antara asupan lemak dan asupan kerbohidrat dengan status gizi, namun asupan lemak dan karbohidrat patut diwaspadai agar tidak mengonsumsinya secara berlebihan. Kelebihan lemak akan disimpan tubuh dalam bentuk cadangan lemak sehingga tubuh akan mengalami peningkatan berat badan (24). Sedangkan, karbohidrat yang dikonsumsi dalam jumlah berlebih akan menyebabkan kegemukan karena karbohidrat yang tidak terpakai akan disimpan dalam bentuk jaringan lemak (25).

Aktivitas fisik umumnya diartikan sebagai gerak tubuh yang ditimbulkan oleh otot-otot skeletal dan mengakibatkan pengeluaran energi. Aktivitas fisik dibutuhkan untuk salah satu upaya menyeimbangkan antara pengeluaran dan pemasukan zat gizi sehingga diharapkan dapat membuat berat badan menjadi ideal. Aktivitas fisik pada dewasa cenderung rendah yang disebabkan oleh beberapa faktor seperti kesibukan dan gaya hidup yang kurang baik (2). Hasil data aktivitas fisik pada penelitian ini menunjukkan seluruh responden memiliki aktivitas fisik ringan. Berdasarkan observasi peneliti, hal ini disebabkan oleh pandemi yang mengharuskan responden untuk berkegiatan dirumah seperti WFH (Work Form Home) ataupun kuliah secara daring sehingga mengurangi aktivitas fisik responden.

Selain asupan dan aktivitas fisik, kami juga mengukur kualitas tidur dimana kami mengukur mutu tidur seseorang yang mendapatkan jumlah tidur rapid eye movement (REM) dan non rapid eye movement (NREM) yang sesuai (26). Faktor yang dapat mempengaruhi kualitas tidur diantaranya yaitu waktu yang dibutuhkan untuk memulai tidur (sleep latency), durasi tidur (sleep duration), presentase antara durasi tidur dengan waktu yang dihabiskan di tempat tidur (sleep efficiency), gangguan tidur saat malam hari (sleep disturbance), penggunaan obat tidur, gangguan yang kerap dialami saat siang hari dan kualitas tidur yang dilnilai secara subjektif (subjective sleep quality) (7). Pada penelitian ini, kualitas tidur dibagi menjadi dua kategori yaitu kualitas tidur buruk dan kualitas tidur baik. Hasil uji chi square pada penelitian ini diperoleh adanya hubungan antara kualitas tidur dengan status gizi. Hal ini sejalan dengan penelitian yang dilakukan oleh Khasan (2017) juga menunjukkan adanya hubungan yang signifikan antara kualitas tidur dengan status gizi dengan $p$-value $=0,000$. Penelitian tersebut didapatkan pada kelompok kualitas tidur yang buruk dapat berhubungan dengan status gizi yang berlebih dan penurunan waktu tidur pada seseorang akan mengakibatkan berbagai efek bagi tubuh dan pikiran (27).

Seseorang yang mengalami penurunan pada kualitas tidur mengalami ketidakseimbangan antara hormon ghrelin dan leptin yang merupakan hormon perangsang dan peredam nafsu makan serta dapat menyebabkan gangguan keseimbangan di dalam tubuh (28).

Nutrire Diaita Vol.13, No.02, Oktober 2021 ,p.48-55 
Tabel 2.

Hubungan asupan energi dan zat gizi makro, kualitas tidur, tingkat stres, dan screen time dengan status gizi

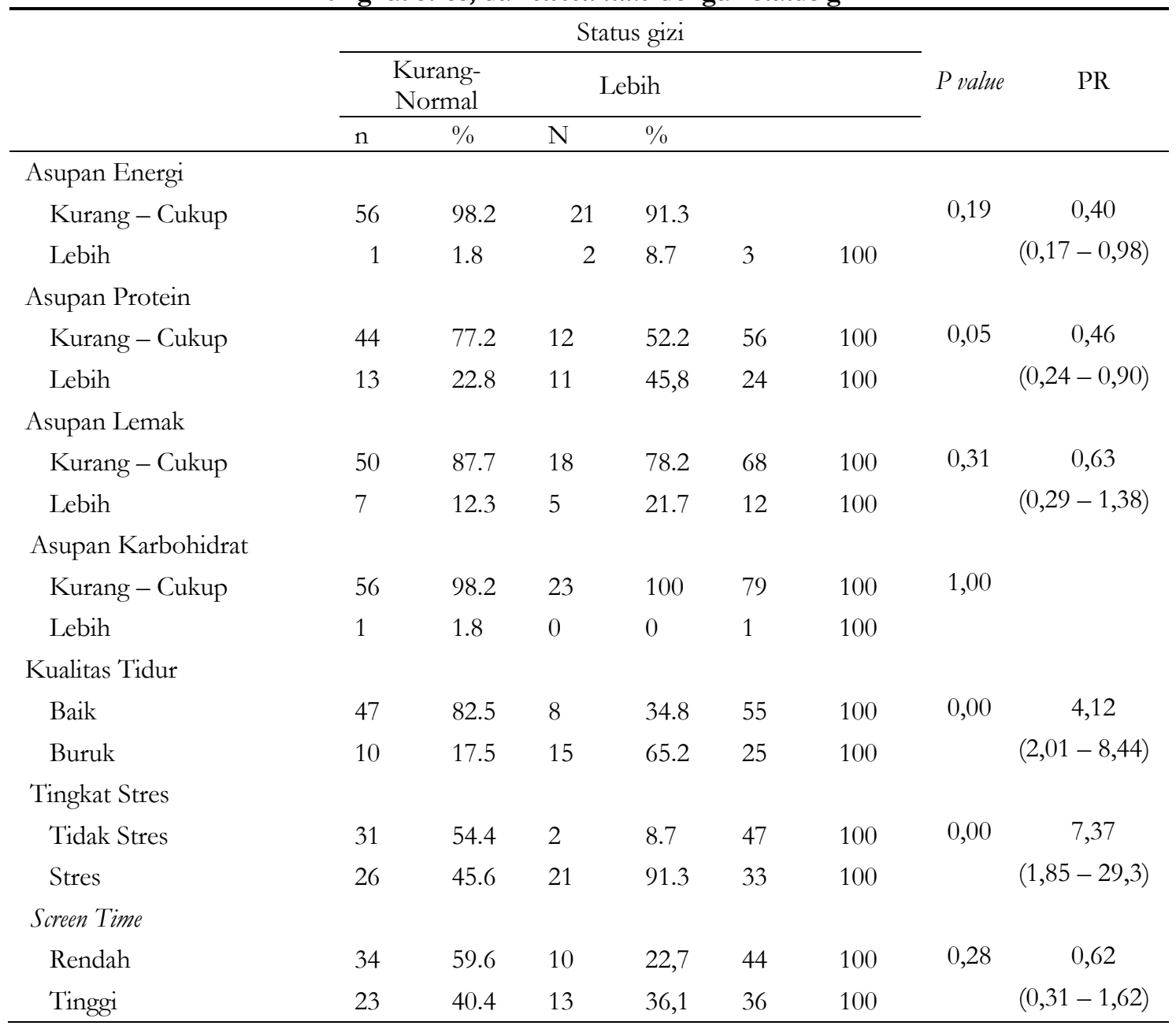

Stress juga faktor yang kami ukur. Stres adalah sebuah kondisi yang ditimbulkan oleh interaksi antara seseorang dengan lingkungannya yang mendatangkan kesenjangan dari desakan-desakan dengan keadaan sistem biologis, psikis, dan sosial seseorang (29). Pasa dewasa awal cukup rentan terhadap permasalahan. Permasalahan ini bisa didapatkan dari faktor dalam ataupun luar. contohnya seperti teman sebaya, masyarakat ataupun keluarga. Jika permasalah tersebut tidak dapat diterima atau diselesaikan dengan baik maka akan mempengaruhi kondisi psikologis seseorang (1). Hasil uji chi square pada penelitian ini diperoleh adanya hubungan antara tingkat stress dengan status gizi. Pada masa pandemic Covid-19 seperti sekarang ini, kondisi stress dapat diklasifikan menjadi 3 ruang lingkup yaitu stress akademik yang terjadi pada siswa/mahasiswa, stress kerja dan stress keluarga. Hal tersebut dapat dikarenakan kebijakan WHF (work from bome) untuk menahan penyebaran Covid-19. Dimana terdapat dampak negatif bagi kelompok dewasa awal yaitu aktivitas yang terbatas, perputaran ekonomi yang berkurang, pemutusan hubungan pekerjaan dari tempat bekerja, kejenuhan dalam belajar serta kurangnya interaksi langsung antara pelajar dan pengajar. Dampak negative tersebut sangat mungkin menimbulkan stress yang dialami oleh mahasiswa dan karyawan/ pekerja (30). Saat seseorang mengalami stres, tubuhnya akan otomatis mengeluarkan hormon kortisol secara berlebih dari kelenjar adrenal. Hormon kortisol yang tinggi dapat memicu tubuh untuk mengeluarkan hormon insulin, hormon leptin, dan sistem neuropeptide $Y$ (NPY) sehingga merangsang otak untuk menaikkan rasa lapar dan rasa ingin makan makanan tinggi gula, berlemak dan berkalori tinggi (31).

Screen time adalah waktu yang digunakan seseorang dalam sehari untuk aktivitas di depan layar elektronik 
seperti handphone, komputer, laptop, dan lainnya. Pada penelitian ini, screen time dibagi menjadi dua kategori yaitu rendah dan tinggi. Penentuan rendah dan tinggi nya diliat dari nilai rata-rata atau nilai mean. Hasil uji chi square pada penelitian ini diperoleh ada tidaknya hubungan antara tingkat stres dengan status gizi. Hasil penelitian sejalan dengan penelitian yang dilakukan oleh Mardiyati, N. L (2018) yang menunjukkan bahwa tidak terdapat hubungan antara screen time dengan kenaikan berat badan (32). Hal ini dikarenakan banyak faktor yang menyebabkan kenaikan berat badan salah satunya yaitu kurangnya aktivitas fisik. Kondisi pandemi juga turut mempengaruhi, yang mana durasi penggunaan gadget di masa pandemi bertambah karena hampir seluruh kegiatan kuliah ataupun kerja menggunakan gadget. Sebagian besar responden menghabiskan waktu untuk menggunakan handphone. Aktivitas layar yang paling sering untuk bermain game, menonton serial drama atau film serta bermain media sosial.

\section{Kesimpulan}

Ada hubungan bermakna antara kualitas tidur dan tingkat stres terhadap status gizi pada orang dewasa di Kelurahan Kota Bambu Utara. Namun, tidak ada hubungan bermakna antara asupan energi dan zat gizi makro dan screen time dengan status gizi pada orang dewasa di Kelurahan Kota Bambu Utara, Jakarta Barat. Orang dewasa perlu menjaga kualitas tidur dengan baik dan mampu memanajemen stress selama Pandemi berlangsung sehingga status gizi tetap optimal.

\section{Daftar Pustaka}

1. Fernanda, PA. Pentingnya Orang Dewasa Awal Menyelesaikan Tugas Perkembangannya. SCHOULID Indones J Sch Couns. 2019; 3(2):35-40.

2. $\quad$ Kemenkes R. Gizi Dalam Daur Kebidupan (1st ed.). Jakarta; 2017.

3. Sulistyoningsih H. Gizi Untuk Kesehatan Ibu dan Anak. Yogyakarta: GRAHA ILMU; 2011.

4. Serly V, Sofian A, Ernalia Y. Hubungan Body Image, Asupan Energi Dan Aktivitas Fisik Dengan Status Giri Pada Mahasiswa Fakultas Kedokteran Universitas Riau Angkatan 2014. J FK. 2015; 2(2):1-14.

5. Watson F, Minarto D, Rah JH, Maruti AK. Pembangunan Gizi Di Indonesia. Direktorat Kesehatan dan Gizi Masyarakat Kementerian PPN/Bappenas; 2019.

6. $\quad$ Kemenkes R. Penilaian Status Gizi (1st ed). Jakarta; 2017.

7. Yi H. Sleep quality and its associated factors in adults. J Korean Public Heal Nursing. 2013; 27(1):76-88.

8. Taquet M, Luciano S, Geddes JR, Harrison PJ. Bidirectional associations between COVID-19 and psychiatric disorder: retrospective cohort studies of 62354 COVID-19 cases in the USA. The Lancet Psychiatry. 2021; 8(2):130-140.

9. Giuntella O, Hyde K, Saccardo S, Sadoff S. Lifestyle and mental health disruptions during COVID-19. Proc Natl Acad Sci. 2021;118(9).

10. Sultana A, Tasnim S, Hossain MM, Bhattacharya S, Purohit N. Digital screen time during the COVID-19 pandemic: $A$ public health concern. F1000Research. 2021;10(81).

11. Fikawati S. Gizi Anak dan Remaja (1sted.). Jakarta: Rajawali Pers; 2017.

12. Gibson RS. Principles of nutritional assessment. USA: Oxford University Press; 2005.

13. Van Poppel MN, Chinapaw MJ, Mokkink LB, Van Mechelen W, Terwee CB. Physical activity questionnaires for adults. Sport Med. 2010;40(7): 565-600.

14. Buysse DJ, Reynolds III CF, Monk TH, Berman SR, Kupfer DJ. The Pittsburgh Sleep Quality Index: a new instrument for psychiatric practice and research. Psychiatry Res. 1989; 28(2): 193-213.

15. Parkitny, L., \& McAuley J. The depression anxiety stress scale (DASS). J Physiother. 2010; 56(3): 204.

16. Rahmawati, T. Hubungan Asupan Zat Gizi Dengan Status Gizi Mabasiswa Gizi Semester 3 Stikes PKU Muhammadiyah Surakarta. Profesi (Profesional Islam): Media Publikasi Penelitian. 2017; 14(2): 49-57.

17. Poetry et al. Perbedaan Konsumsi Energi dan Zat Gizi Makro Berdasarkan Status Gizi Mahasiswa Fakultas Kesehatan Maysarakat Universitas Airlangga. Media Gizi Indonesia. 2020; 15(1): 52-59.

18. Wehling, H., \& Lusher J. People with a body mass index $\geqslant 30$ under-report their dietary intake: a systematic review. J Heal Psychol. 2019; 24(14): 2042-2059.

19. Sumarna et al. Hubungan Antara Obesitas Dengan Kualitas Tidur Pada Mahasiswa Fakultas Keperawatan Universitas Padjadjaran Kampus Garut. J Kesehat Bakti Tunas Husada J Ilmu Ilmu Keperawatan, Anal Kesehat dan Farm. 2020; 20 (1):112-118

20. Tan ST, Tan SS, Tan CX. Screen time-based sedentary behaviour, eating regulation and weight status of university students during the COVID-19 lockdown. Nutr Food Sci. 2021.

21. Fathonah IS, Sarwi MS. Literasi Zat Giri Makro Dan Pemecahan Masalabnya. Deepublish. 2020. 
22. Murray RK, Granner DK, Rodwell VW. Biokimia Harper Edisi 27. Jakarta: Buku Kedokteran EGC; 2009.

23. Nugroho. Keperawatan gerontic \& Geriatrik (3 ed). Jakarta: EGC; 2009.

24. Whitney E, Rolfes SR. Understanding nutrition, thirteenth edition (13th ed). Belmont: Thomson Wadsworth; 2013.

25. Almatsier S. Prinsip Dasar Ilmu Gizi. Jakarta: PT Gramedia Pustaka Utama; 2001.

26. Sendir M, Acaroglu R, Kaya H, Erol S, Akkaya Y. Evaluation of quality of sleep and effecting factors in hospitalized neurosurgical patients. Neurosci. 2007; 12(3): 226-231.

27. Khasan N, Sidarta N. Hubungan Kualitas Tidur dengan Status Gizi Pada Anak SMA. 2017; (I): 1-16.

28. Odgen CL. Prevalence of High Body Mass Index in US Children and Adolescents, 2007-2008. JAMA. 2010; 303(3).

29. Chrousos GP. Stress and disorders of the stress system. Nat Rev Endocrinol. 2009; 5(7): 374-381.

30. Muslim M. Manajemen Stres Pada Masa Pandemi COVID-19. J Manaj Bisnis. 2020; 23(2).

31. Sinha R, Gu P, Hart R, Guarnaccia JB. Food craving, cortisol and ghrelin responses in modeling bighly palatable snack intake in the laboratory. Physiol Behav. 2019; 208: 112563.

32. Mardiyati NL. Screen time dengan konsumsi sayur dan buah serta kenaikan berat badan pada mahasiswa Fakultas Ilmu Kesehatan. J Nutr. 2018; 20(2): 53-60. 